\title{
SUPERVISI PEMBELAJARAN KEPALA MADRASAH DALAM MENINGKATKAN KOMPETENSI PEDAGOGIK GURU DI MADRASAH ALIYAH GHOYATUL JIHAD KABUPATEN KARAWANG
}

\author{
Alief Aryudha, Tajudin Noor, Sayan Suryana \\ Universitas Singaperbangsa Karawang \\ Email : aliefaryudha@gmail.com, tajudin.noor@fai.unsika.ac.id, \\ sayan.suryana@fai.unsika.ac.id
}

\begin{abstract}
Abstrak
Penelitian ini bertujuan untuk mendeskripsikan pelaksanaan supervisi pembelajaran oleh kepala madrasah di Madrasah Aliyah Ghoyatul Jihad Kabupaten Karawang dilihat dari aspek: 1. Perencanaan supervisi pembelajaran, 2. Pelaksanaan supervisi pembelajaran, 3. Hubungan antara perencanaan dan pelaksanaan supervisi pembelajaran. Supervisi Pembelajaran Kepala Madrasah pada dasarnya suatu kegiatan pelayan untuk guru yang dilakukan kepala madrasah untuk pembinaan kepada guru khususnya agar kualitas pembelajarannya meningkat. Sebagai dampak meningkatnya kualitas pembelajaran tentu dapat meningkat pula prestasi belajar siswa dan itu berarti meningkatlah kualitas lulusan madrasah itu sendiri. Sehingga supervisi pembelajaran terhadap guru diharapkan dapat terlaksana secara berkelanjutan agar kompetensi pedagogik guru dapat meningkat. Metode penelitian yang peneliti gunakan dalam melakukan penelitian ini yaitu metode kualitatif deskriptif, dimana peneliti mendeskripsikan dan menganalisis data-data yang diperoleh di lapangan. Teknik pengumpulan data dilakukan melalui observasi, wawancara dan dokumentasi. Tujuan dari penelitian ini adalah untuk mengetahui dan menganalisa implementasi supervisi pembelajaran yang dilakukan oleh kepala madrasah di Madrasah Aliyah Ghoyatul Jihad. Dari hasil penelitian dapat disimpulkan bahwa pelaksanaan supervisi pembelajaran sudah efektif karena kepala madrasah ketika melakukan supervisi pembelajaran mengacu pada program perencanaan yang sudah di buat untuk meningkatkan kompetensi pedagogik guru.
\end{abstract}

Kata Kunci: Supervisi Pembelajaran, Supervisi Pembelajaran Kepala Madrasah, Kompetensi Pedagogik Guru

\begin{abstract}
This study aims to describe the implementation of learning supervision by the headmaster in Madrasah Aliyah Ghoyatul Jihad Karawang Regency viewed from aspects: 1. Planning learning supervision, 2. Implementation of learning supervision, 3. The relationship between planning and implementing learning supervision. Supervision of Madrasah Principal Learning is basically a servant activity for teachers conducted by madrasah principals for coaching teachers especially to improve the quality of learning. As an impact of increasing the quality of learning can certainly also increase student learning achievement and that means increasing the quality of madrasah graduates themselves. So that supervision of learning of teachers is expected to be carried out on an ongoing basis so that the teacher's pedagogical competence can increase. The research method used by researchers in conducting this research is descriptive qualitative method, in which the researcher describes and analyzes the data obtained in the field. Data collection techniques are done through observation, interviews and documentation. The purpose of this study is to find out and analyze the implementation of learning supervision conducted by the headmaster in Madrasah Aliyah Ghoyatul Jihad. From the results of the study it can be concluded that the implementation of learning supervision has been effective because the headmaster of madrasas when supervising learning refers to the planning program that has been created to improve teacher pedagogical competence.
\end{abstract}

Key words: Learning Supervision, Madrasah Head Learning Supervision, Teacher's Pedagogical Competencies 


\section{A. PENDAhuluan}

Kepala madrasah berperan dalam meningkatkan Kompetensi Pedagogik guru yang berada di dalam pengawasannya, Pengawasan tersebut yaitu supervisi yang dilakukan oleh kepala madrasah, Kepala madrasah sebagai supervisor berkewajiban membina para guru agar menjadi pendidik dan pengajar yang baik. Berkaitan dengan hal tersebut kepala madrasah sebagai supervisor mempunyai wewenang untuk mensupervisi guru-guru. Kepala madrasah sebagai supervisor mempunyai tanggung jawab terhadap pembinaan dan pemberian bantuan terhadap guru-guru. Dalam perannya sebagai supervisor kepala madrasah diharapkan dapat membantu guru-guru secara profesional untuk mengatasi masalah dalam kegiatan belajar mengajar. Bantuan dan pelayanan yang diberikan oleh kepala madrasah disesuaikan dengan kebutuhan serta masalah yang sedang dihadapi oleh guru baik secara individu maupun kelompok. Kualitas mengajar guru secara langsung maupun tidak langsung dapat mempengaruhi kualitas pembelajaran, Untuk itu diperlukan pembinaan terus-menerus dari kepala madrasah yaitu melalui supervisi. Untuk mengembangkan kompetensi tersebut seorang guru membutuhkan bantuan berupa bimbingan yang terencana dari seorang supervisor.

Supervisi pembelajaran menurut Glickman (2003:63) adalah serangkaian kegiatan membantu guru dalam mengembangkan kemampuannya mengelola proses belajar mengajar untuk mencapai tujuan pembelajaran. Sedangkan menurut (Hawkins, 2005:39) supervisi pembelajaran adalah proses pemberian bantuan kepada guru dengan jalan memberikan dorongan, rangsangan atau bimbingan untuk memperbaiki dan meningkatkan proses belajar mengajar. Pada dasarnya hakekat supervisi pembelajaran bukan menilai kinerja guru dalam mengelola proses belajar mengajar, tetapi membantu guru mengembangkan kemampuannya. Evaluasi terhadap guru dilakukan dalam rangka menggali data yang ditindak lanjuti dengan pembinaan dan pengembangan kemampuan guru. Dalam hal ini Soetopo (2007:86) mengemukakan 3 aspek evaluasi keberhasilan guru, yaitu aspek personal guru, aspek profesional guru, aspek sosial guru. Aspek personal guru meliputi penampilan sehari-hari, cara berbicara dan berinisiatif, keseimbangan emosi,

\section{B. METODE PENELITIAN}

Penelitian yang dilakukan oleh peneliti yaitu dengan menggunakan pendekatan kualitatif dengan metode deskriptif analisis melalui penelitian lapangan, yaitu dengan mendeskripsikan atau menjelaskan sesuatu hal seperti apa adanya sehingga memberi gambaran yang jelas tentang situasi- keramahtamahan; aspek profesional meliputi perencanaan mengajar, pelaksanaan kegiatan belajar mengajar, evaluasi pembelajaran; dan aspek sosial meliputi hubungan dengan kepala madrasah, guru yang lain, petugas tata usaha, petugas lainnya, murid, orang tua murid, dan masyarakat. Melalui evaluasi terhadap keberhasilan guru tersebut maka akan ditemukan tingkat keberhasilan dan ketidakberhasilan guru sehingga pembinaan dan pengembangan kemampuan guru dapat dilaksanakan secara tepat. (Kadim, 2013:103).

Untuk mengetahui bagaimana guru melaksanakan pembelajaran secara berkala, kepala madrasah melaksanakan kegiatan supervisi pembelajaran, yang dapat dilakukan melalui kegiatan kunjungan kelas untuk mengamati proses pembelajaran secara langsung, terutama dalam pemilihan dan penggunaan metode, media yang digunakan dan keterlibatan siswa dalam proses pembelajaran. Dari hasil supervisi ini, kepala madrasah dapat mengetahui kelemahan guru yaitu dalam kompetensi pedagogiknya, tingkat penguasaan kompetensi guru yang bersangkutan, selanjutnya diupayakan solusi, pembinaan dan tindak lanjut tertentu sehingga guru dapat memperbaiki kekurangan yang ada sekaligus mempertahankan keunggulannya dalam melaksanakan pembelajaran. Menurut Ngalim Purwanto (2008:76) Supervisi adalah suatu aktivitas pembinaan yang direncanakan untuk membantu para guru dan pegawai madrasah lainnya dalam melakukan pekerjaan mereka secara efektif. Sedangkan menurut Sahertian (2010:19) Supervisi juga dimaknai sebagai usaha memberi layanan kepada guru-guru baik secara kelompok maupun individual dalam memperbaiki pengajaran. Dengan demikian, pada hakikatnya supervisi adalah kegiatan pembinaan terhadap para guru dan tenaga kependidikan melalui teknik-teknik tertentu dengan tujuan untuk menciptakan efektivitas kinerja mereka dalam menjalankan tugasnya. Peningkatan kinerja guru melalui supervisi dan monitoring pengawas bukan sekedar diarahkan kepada pembinaan yang lebih bersifat aspekaspek administratif kepegawaian tetapi harus lebih kepada peningkatan kemampuan keprofesionalannya dan komitmen sebagai seorang guru (E.Mulyasa, 2007:13)

situasi di lapangan. Penelitian deskriptif yaitu penelitian yang berusaha untuk pemecahan masalah yang ada sekarang berdasarkan datadata. Jadi peneliti menyajikan data, menganalisis data dan menginterprestasi. Peneliti mengumpulkan data bukan berupa angka-angka melainkan data tersebut berasal dari naskah wawancara, catatan lapangan, dokumen pribadi, catatan atau memo, gambar 
(foto) dan dokumen resmi lainnya. Peneliti sebagai instrumen kunci pengambilan sampel sumber data dilakukan secara tetap dan berkembang, teknik pengumpulan dengan analisis data bersifat kualitatif, dan hasil penelitian kualitatif lebih menekankan makna.

\section{HASIL DAN PEMBAHASAN}

1. Perencanaan Supervisi Pembelajaran Kepala Madrasah dalam Meningkatkan Kompetensi Pedagogik Guru

$$
\text { Menurut sudiyono }
$$

perencanaan supervisi pembelajaran yaitu program yang meliputi, Objektif (data apa adanya), bertanggung jawab, berkelanjutan, didasarkan pada standar nasional pendidikan, kebutuhan dan kondisi madrasah itu sendiri. Perencanaan pada hakikatnya dijadikan sebagai acuan dalam pelaksanaan supervisi pembelajaran untuk memperkirakan atau memproyeksikan apa yang harus dilakukan dan bagaimana hasil yang diperoleh. Berdasarkan hasil wawancara peneliti dengan kepala madrasah terungkap bahwa dalam menyusun perencanaan supervisi pembelajaran, kepala madrasah mempertimbangkan faktor-faktor yang mempengaruhi supervisi diantaranya yaitu keadaan guru dan teknik yang akan diterapkan dalam pelaksanaan supervisi pembelajaran itu sendiri.

Sama halnya dengan Suhertian (2008:20) yang menyatakan bahwa perencanaan supervisi pembelajaran yaitu berdasarkan data yang objektif dalam proses pembelajaran yang dilaksanakan secara sistematis terencana dan continue. Dari perencanaan supervisi pembelajaran menunjukan bahwa perencanaan supervisi pembelajaran dijadikan pedoman kegiatan kepengawasan dengan tujuan mengetahui apa yang harus dipersiapkan dan apa yang harus dikerjakan sehingga kegiatan supervisi pembelajaran menjadi lebih terarah dan bisa berjalan dengan lancar. Kepala Madrasah Aliyah Ghoyatul Jihad menyusun rencana untuk meningkatkan kompetensi pedagogik guru karna di setiap bidang kegiatan memerlukan perencanaan yang sistematik dan prospektif untuk mencapai tujuan secara efektif. Supervisi pembelajaran kapala madrasah yaitu usaha untuk mendorong para guru untuk mengembangkan kompetensinya agar dapat mencapai tujuan pendidikan secara efektif. Oleh karna itu dalam supervisi pembelajaran di Madrasah Aliyah Ghoyatul Jihad perencanaan kegiatan perlu dirancang sebaik-baiknya. Tanpa perencanaan yang baik supervisi pembelajaran hanya memberikan kekecewaan kepada pihakpihak yang terlibat didalamnya, yaitu guru, kepala madrasah, dan murid-murid yang mengharapkan pembelajaran dapat berlangsung secara aktif, efektif, kreatif dan menyenangkan.

Perencanaan supervisi pembelajaran menyangkut semua komponen yang terkait dalam pelaksanaan supervisi pembelajaran, komponen tersebut meliputi aspek personil, dan aspek operasional dalam supervisi pembelajaran. Kepala Madrasah Aliyah Ghoyatul Jihad menyusun rencana untuk memperkuat implementasi kompetensi pedagogik guru. Oleh karena itu kepala madrasah memiliki visi misi kepengawasan yang diimplementasikan ke dalam perencanaan, pelaksanaan, dan evaluasinya. Kurang efektifnya pelaksanaan supervisi pembelajaran di madrasah aliyah ghoyatul jihad selama ini karena kurang jelasnya visi dan misi kepengawasan yang dilakukan oleh pengawas. Guru sebagai obyek binaan tidak pernah dilibatkan dalam penyusunan program supervisi pembelajaran. Pelaksanaan supervisi pembelajaran pun terkesan asal dilaksanakan dan tidak mengacu pada kebutuhan guru sehingga menimbulkan kurangnya kepercayaan guru terhadap kepala madrasah untuk menyelesaikan problematika pembelajaran. Namun hal ini sudah tidak lagi terjadi di Madrasah Aliyah Ghoyatul Jihad karna kepala madrasah sudah menyusun program perencanaan yang menjadi perhatian utama kepala madrasah yaitu untuk meningkatkan kompetensi pedagogik guru dam aspek pembelajaran

Berdasarkan hasil observasi dan informasi yang didapat dari informan dalam hal ini kepala Madrasah Aliyah Ghoyatul Jihad dan guru-guru yang diwawancarai, Tedapat beberapa program perencanaan supervisi pembelajaran dalam meningkatkan kompetensi pedagogik guru yaitu sebagai berikut:

a. Meningkatkan kompetensi dalam melaksanakan proses pembelajaran

b. Meningkatkan komepetensi menganalisa hasil penilaian

c. Meningkatkan kompetensi menilai dan mengevaluasi proses pembelajaran

d. Meningkatkan kompetensi melaksanakan pembelajaran sesuai hasil evaluasi

e. Meningkatkan kompetensi menyusun pembelajaran

f. Meningkatkan kompetensi menyusun RPP

g. Meningkatkan kompetensi membimbing guru pemula dalam program perencanaan

h. Meningkatkan kompetensi membimbing siswa dalam kegiatan ekstrakurikuler

i. Meningkatkan kompetensi pedagogik guru

j. Meningkatkan kompetensi melakukan pengembangan diri

k. Meningkatkan kompetensi melaksanakan publikasi ilmiah

1. Meningkatkan kompetensi membuat karya inovatif 
Terdapat beberapa aspek yang menjadi prioritas dalam menyusunan program perencanaan supervisi pembelajaran menuju madrasah yang efektif yaitu;

a. Fokus pada kualitas pembelajaran

b. Keefektifan pencapaian indikator pembelajaran

c. Berorientasi pada visi, misi madrasah

d. Harapan yang tinggi bagi semua peserta didik

e. Akuntabilitas pengelolaan madrasah.

2. Pelaksanaan Supervisi Pembelajaran Kepala Madrasah dalam Meningkatkan Kompetensi Pedagogik Guru

Menurut Iskandar (2009:51)

Pelaksanaan supervisi pembelajaran yaitu serangkaian kegiatan guna membantu guru dalam mengembangkan kemampuan mengelola proses pembelajaran demi pencapaian tujuan pembelajaran. Pelaksanaan supervisi pembelajaran oleh kepala madrasah terhadap guru sangat penting dilakukan dalam rangka meningkatkan kompetensi guru dan kualitas pembelajaran melalui proses pembelajaran yang baik. Dalam melaksanakan supervisi pembelajaran kepala madrasah harus memperlakukan guru sebagai orang yang berpotensi untuk maju dan berkembang lebih baik, sehingga tidak berkesan pelaksanaan supervisi hanya mencari kesalahan-kesalahan guru dalam melaksanakan tugas tetapi lebih diarahkan kepada proses pembinaan secara sistematis dan berkelanjutan.

Berdasarkan hasil observasi dan informasi yang didapat dari informan yakni kepala madrasah dan guru-guru di Madrasah Aliyah ghoyatul Jihad yang diwawancarai, dalam hal ini pelaksanaan supervisi pembelajaran kepala Madrasah Aliyah Ghoyatul Jihad dalam melaksanakan kegiatan supervisi pembelajaran dengan teknik sebagai berikut;

\section{a. Kunjungan Kelas}

Pelaksanaan supervisi pembelajaran kepala madrasah di MA Ghoyatul Jihad dilakukan dengan cara kunjungan kelas. Dengan kunjungan kelas kepala madrasah ghoyatul jihad dapat mengetahui apakah guruguru menjalankan proses pembelajaran sesuai dengan perencanaan RPP yang telah disusun, serta melihat secara langsung kompetensi pedagogik guru saat mengajar dikelas. Berikut yang dilakukan kepala Madrasah Ghoyatul Jihad dalam kunjungan kelas yaitu sebagai berikut:

1. Memfokuskan perhatian pada komponen-komponen dan situasi pemebalajaran dikelas

2. Bertumpu pada upaya memajukan proses pemebalajaran
3. Membantu guru-guru untuk memajukan proses pembelajaran

4. Membantu guru-guru agar dapat mengevaluasi diri sendiri

5. Secara bebas memberikan kesempatan kepada guru agar dapat berdiskusi dengannya mengenai problema-problema yang dihadapinya dalam proses pembelajaran mereka

Dalam hal ini terdapat beberapa kriteria yang diperhatikan dalam kunjungan kelas antara lain sebagai berikut;

1. Mengungkapkan aspek-aspek yang dapat dipergunakan untuk memperbaiki dan meningkatkan kompetensi guru

2. Terjadi interaksi antara pihak yang membina dan yang dibina

3. Memiliki tujuan yang jelas

4. Memakai lembaran observasi

5. Tidak mengganggu proses pembelajaran

Kunjungan ini berturut-turut dalam pelaksanaan supervisi pembelajaran, sebab tanpa kunjungan kelas maka meningkatkan kompetensi pedagogik guru tidak dapat diketahui secara obyektif oleh kepala MA ghoyatul jihad.

b. Observasi Kelas

Dalam observasi kelas ini, kepala madrasah secara langsung mengobservasi, meneliti suasana kelas selama pembelajaran berlangsung. Tujuannya yaitu untuk memperoleh data seobyektif mungkin sehingga dengan bahan yang diperoleh dapatlah digunakan dalam menganalisa kesulitankesulitan yang dihadapi para guru dalam usaha memperbaiki belajar-mengajar. Namun yang paling penting perlu diperhatikan supervisor ketika mengadakan observasi adalah;

1. Mengamati keseluruhan proses belajar mengajar dalam satu pertemuan

2. Mengamati aktivitas belajar mengajar secara keseluruhan

3. Tidak berpartisipasi dalam proses belajar mengajar

\section{c. Pertemuan Pribadi}

Pertemuan pribadi ini dilakukan secara formal dan informal atau langsung dan tidak langsung dengan perkembangan teknologi komunikasi yang semakin canggih pertemuan tidak langsung atau informal bisa lebih efektif. Berikut ini pertemuan pribadi yang dilaksanakan oleh kepala Madrasah Aliyah Ghoyatul Jihad sesudah kunjungan kelas;

1. Memprogramkan pertemuan pribadi secara bersama-sama dengan guruguru

2. Merumuskan tujuan pertemuan pribadi 
3. Merumuskan prosedur pertemjuan pribadi

4. Membantu memecahkan masalah yang dihadapi oleh guru dalam pertemuan pribadi.

\section{d. Rapat Dewan Guru}

Rapat dewan guru yang dilakukan oleh kepala madrasah dalam meningkatan kompetensi pedagogik guru yaitu rapat dengan guru. Rapat pertemuan antara semua guru dengan kepala madrasah yang dipimpin oleh bapak H. Jaenul Anwar sebagai kepala Madrasah Aliyah Ghoyatul Jihad untuk membahas segala hal yang menyangkut pendidikan dan kegiatan pembelajaran di madrasah. Kepala Madrasah Aliyah Ghoyatul Jihad memprogramkan beberapa pertemuan secara berjenjang, misalkan seperti hari senin diagendakan untuk rapat guru-guru, sedangkan hari kamis dijadwalkan rapat khusus pimpinan madrasah dengan agenda membahas berbagai permasalahan yang disampaikan pada saat rapat guru. Berikut ini yang dilakukan kepala Madrasah Aliyah Ghoyatul Jihad ketika rapat dewan guru yaitu;

1. Merusmuskan tujuan rapat

2. Memimpin rapat

3. Membahas masalah-masalah penting dalam rapat

4. Menghidupkan suasana rapat

5. Mengaitkan rapat dengan pembinaan kompetensi pedagogik guru

6. Menjadikan rapat sebagai tempat untuk tukar pikiran

7. Menyimpulkan hasil rapat

Namun dalam rapat dewan guru ini ada beberapa hal yang diperhatikan oleh kepala madrasah sebagai pemimpin rapat yaitu;

1. Menciptakan situasi yang nyaman dengan sikap ramah tamah, menjadi pendengar yang baik terhadap perdapat-pendapat atau ide-ide dari peserta rapat

2. Menguasai ruang lingkup masalah dan materi yang dibicarakan dalam rapat

3. Menumbuh kembangkan motivasi pada diri peserta rapat untuk berpartisipasi secara aktif selama rapat berlangsung

4. Mengatur arah dan fokus pembicaraan selama rapat berlangsung, serta menghindari topik pembicaraan yang tidak relevan

5. Memberikan penjelasan tambahan secara obyektif terkait usul dari peserta rapat

6. Mencari titik persamaan dan menetralisasi perbedaan fokus masalah utama yang dipecahkan bersama, sehingga menjadi kesempatan pendapat antara pemimpin rapat dan peserta rapat

7. Pemimpin mengakhiri rapat dengan manfaat yang besar dan memuaskan semua peserta rapat

\section{e. Seminar dan Workshop}

Seminar digunakan kepala Madrasah Aliyah Ghoyatul Jihad dalam membina guru untuk meningkatkan kompetensi pedagogiknya. Karna seminar yaitu salah satu kegiatan yang efektif untuk membina guru secara kelompok. Seminar ini menyajikan karya tulis baik berupa makalah, ataupun hasil-hasil penelitian. Tujuan diadakannya seminar ini untuk membahas berbagai informasi, ide, konsep dan temuan penelitian melalui suatu forum seminar. Karna seminar ini sebagai bentuk belajar mengajar kelompok untuk mengadakan pendalaman atau kesadaran tersendiri bersama-sama terhadap berbagai masalah yang dihadapi. Seminar ini dilaksanakan oleh kepala Madrasah Aliyah Ghoyatul Jihad yang diikuti secara terbuka, namun untuk dilingkungan madrasah saja. Kepala Madrasah Aliyah Ghoyatul Jihad menggunakan seminar ini untuk membantu guru-guru dalam meningkatkan kompetensi pedagogiknya.

Sedangkan Workshop juga salah satu yang digunakan kepala madrasah untuk membina guru secara kelompok, Karna workshop merupakan sebuah kegiatan atau acara yang dirancang untuk mengajarkan atau memperkenalkan kepada guru-guru, Dimana para narasumber yang memiliki keahlian dibidang tertentu berkumpul untuk membahas masalah yang di alami oleh guru-guru dalam proses pembelajaran. Dalam pelaksanaan workshop di Madrasah Aliyah Ghoyatul Jihad memiliki beberapa tujuan yang berisi: Mendiskusikan berbagai aspek topik, mempelajari, mempraktekkan, dan mengevaluasi topik tersebut setelahnya

Pelaksanaan supervisi pembelajaran kepala Madrasah Aliyah Ghoyatul Jihad yaitu kegiatan yang membantu guru untuk meningkatkan kompetensi pedagogik guru dalam mengelola proses belajar mengajar demi pencapaian tujuan pembelajaran. Kondisi kelas dengan strategi belajar kooperatif memberikan dukungan yang berarti bagi siswa bahwa kualitas lingkungan kelas di madrasah memiliki pengaruh signifikan terhadap belajar siswa. Dengan begitu siswa dapat belajar dengan baik ketika mereka merasa lingkungan kelas lebih positif. Dalam pembelajaran ini guru harus bisa mengkreasikan pembelajaran, melalui penerapan giat belajar. Penerapan ini membutuhkan kompetensi pedagogik guru yang komprehensif. Pada pembelajaran kontekstual, guru berperan sebagai fasilitator, dan pembelajaran berpusat pada siswa. Guru-guru dibina agar tidak banyak bergantung pada pengarahan dari supervisor saja, lebih percaya 
diri dan percaya kepada sumber-sumber yang dapat mendukung kapabilitasnya sebagai guru yang profesional

3. Hubungan Perencanaan dan Pelaksanaan Supervisi Pembelajaran Kepala Madrasah dalam Meningkatkan Kompetensi Pedagogik guru

Menurut Hamalik (1992:34) Hubungan antara perencanaan dan pelaksanaan supervisi pembelajaran kepala madrasah yaitu sebuah aspek yang bertujuan untuk meningkatkan kemampuan guru dalam proses pembelajaran yang menghasilkan hasil belajar siswa yang berkualitas. Adanya hubungan perencanaan dan pelaksanaan supervisi kepala madrasah dalam meningkatkan kompetensi pedagogik guru menunjukan bahwa jika perencanaan dan pelaksaan supervisi pembelajaran kepala madrasah ditingkatkan maka kompetensi pedagogik guru akan meningkat.

Sama halnya dengan Mufidah (2009:78) Menyatakan bahwa peningkatan kompetensi pedagogik guru dapat diperoleh dari perencanaan dan pelaksanaan supervisi pembelajaran kepala madrasah yang terfokus pada proses pembelajarannya. Perencanaan pada hakikatnya dijadikan sebagai acuan dalam pelaksanaan supervisi pembelajaran untuk memperkirakan apa yang harus dilakukan dan bagaimana hasil yang diperoleh. Berdasarkan hasil wawancara peneliti dengan kepala madrasah terungkap bahwa dalam menyusun perencanaan supervisi pembelajaran, kepala madrasah mempertimbangkan faktor-faktor yang mempengaruhi supervisi diantaranya yaitu keadaan guru dan teknik yang akan diterapkan dalam pelaksanaan supervisi pembelajaran itu sendiri. Pelaksanaan supervisi pembelajaran perlu dilakukan agar diketahui apakah supervisi pembelajaran yang dilaksanakan telah mencapai target sebagaimana yang telah ditentukan. Pelaksanaan supervisi pembelajaran menentukan sampai seberapa jauh tujuan supervisi pembalajaran yang telah tercapai. Sebagaimana aktivitas pendidikan yang menentukan hasil dalam jangka panjang sama halnya dengan supervisi pembelajaran, karna hasil yang dicapai dalam pelaksanaan supervisi pembelajaran terutama yang kerbenaan dengan proses pembelajaran dapat dilihat dalam jangka panjang

Berdasarkan hasil observasi dan informasi yang didapat dari informan yakni kepala madrasah dan guru-guru di Madrasah Aliyah ghoyatul Jihad yang diwawancarai, dalam hal ini hubungan antara perencanaan dan pelaksanaan supervisi pembelajaran kepala madrasah yang berhubungan dengan kegiatan pembelajaran berupa: a. Menguasai karakteristik peserta didik b. Menguasai prinsip-prinsip pembelajaran c. Mampu mengembangkan Kurikulum yang terkait dengan mata pelajaran d. Mampu menguasai pemanfaatkan Teknologi Informasi dan Komunikasi e. Mampu menguasai Pengembangan potensi peserta didik f. Mampu menguasai berkomunikasi secara empati dan santun g. Mampu menguasai evaluasi proses dan hasil pembelajaran. Karena perencanaan dan pelaksanaan dalam supervisi pembelajaran merupakan langkah awal untuk mengetahui sejauh mana kompetensi pedagogik dapat dikuasai oleh guru, maka pelaksanaan supervisi pembelajaran merupakan implementasi dari perencanaan yang sudah dibuat oleh kepala madrasah untuk meningkatkan kompetensi pedagogik guru.

\section{KESIMPULAN}

1. Perencanaan supervisi pembelajaran kepala madrasah meliputi:

a. Meningkatkan kompetensi dalam melaksanakan proses pembelajaran

b. Meningkatkan kompetensi menganalisa hasil penilaian

c. Meningkatkan kompetensi mengevaluasi proses pembelajaran

d. Meningkatkan kompetensi menyusun pembelajaran

e. Meningkatkan kompetensi menyusun RPP

f. Meningkatkan kompetensi pedagogik guru

2. Pelaksanaan supervisi pembelajaran kepala Madrasah berupa
a. Kunjungan kelas
b. Observasi kelas
c. Pertemuan pribadi
d. Rapat dewan Guru
e. Seminar dan workshop

3. Hubungan perencanaan dan pelaksanaan supervisi pembelajaran kepala madrasah yang berhubungan dengan kegiatan pembelajaran berupa hubungan:

a. Menguasai karakteristik peserta didik

b. Menguasai prinsip-prinsip pembelajaran

c. Mampu mengembangkan kurikulum yang terkait dengan mata pelajaran

d. Mampu menguasai pemanfaatan teknologi informasi dan komunukasi

e. Mampu menguasai berkomunikasi secara empati dan santun

f. Mampu menguasai evaluasi proses dan hasil pembelajaran

\section{DAFTAR PUSTAKA}

E.Mulyasa, Standar Kompetensi dan Sertifikasi Guru (Bandung: Remaja Rosda Karya, 2008)

Glickman, Supervision and Instructional Leadership: A Developmental Approach, $6^{\text {th }}$ Edition, Boston:Ally and bacon, inc 2003.

Hamalik 1992, Administrasi dan Supervisi 
Pengembangan Kurikulum, Bandung:CV Mandar Maju

Hawkins, Supervision in the Helping Professions, New York: Open University Press, 2005

Iskandar, Orientasi Baru Supervisi Pendidikan (Jakarta: Gaung Persada Pers, 2009)

Kadim, Supervisi Pembelajaran dan Kapasitas Guru, (Bandung: Alfabeta, 2013)

Mufidah, Supervisi Pendidikan, (Yogyakarta: Teras, 2009)

Purwanto, Administrasi dan supervisi Pendidikan (Bandung: PT Remaja Rosdakarya, 2009)

Sahertian, Piet A, Konsep Dasar dan Teknik Supervisi Pendidikan dalam Rangka Pengembangan Sumber Daya Manusia, (Jakarta: Rineka Cipta, 2010)

Soetopo, Evaluasi Program Supervisi Pendidikan. Kumpulan materi pendidikan dan pelatihan kepala sekolah menengah, (Jakarta: direktorat Tenaga Kependidikan Ditjen PMPTK, 2007)

Sudiyono, Supervisi Pendidikan, (Penerbit Gaya Media: Yogyakarta, 2002)

Suhertian, Supervisi Pendidikan Dalam Rangka Pengembangan Sumber Daya Manusia, (Jakarta:Rineka Cipta, 2008) 